\title{
Global distribution of carbonate rocks and karst water resources
}

\author{
Nico Goldscheider ${ }^{1} \cdot$ Zhao Chen $^{1} \cdot$ Augusto S. Auler ${ }^{2} \cdot$ Michel Bakalowicz $^{3} \cdot$ Stefan Broda $^{4} \cdot$ David Drew $^{5}$. \\ Jens Hartmann ${ }^{6} \cdot$ Guanghui Jiang $^{7} \cdot$ Nils Moosdorf $^{8,9} \cdot$ Zoran Stevanovic $^{10} \cdot$ George Veni $^{11}$
}

Received: 15 June 2019 / Accepted: 2 March 2020 / Published online: 21 April 2020

(C) The Author(s) 2020

\begin{abstract}
Karst regions offer a variety of natural resources such as freshwater and biodiversity, and many cultural resources. The World Karst Aquifer Map (WOKAM) is the first detailed and complete global geodatabase concerning the distribution of karstifiable rocks (carbonates and evaporites) representing potential karst aquifers. This study presents a statistical evaluation of WOKAM, focusing entirely on karst in carbonate rocks and addressing four main aspects: (1) global occurrence and geographic distribution of karst; (2) karst in various topographic settings and coastal areas; (3) karst in different climatic zones; and (4) populations living on karst. According to the analysis, $15.2 \%$ of the global ice-free continental surface is characterized by the presence of karstifiable

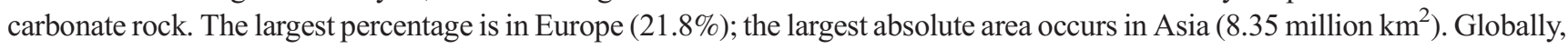
$31.1 \%$ of all surface exposures of carbonate rocks occur in plains, $28.1 \%$ in hills and $40.8 \%$ in mountains, and $151,400 \mathrm{~km}$ or $15.7 \%$ of marine coastlines are characterized by carbonate rocks. About $34.2 \%$ of all carbonate rocks occur in arid climates, followed by $28.2 \%$ in cold and $15.9 \%$ in temperate climates, whereas only 13.1 and $8.6 \%$ occur in tropical and polar climates, respectively. Globally, 1.18 billion people ( $16.5 \%$ of the global population) live on karst. The highest absolute number occurs in Asia (661.7 million), whereas the highest percentages are in Europe (25.3\%) and North America (23.5\%). These results demonstrate the global importance of karst and serve as a basis for further research and international water management strategies.
\end{abstract}

Keywords Carbonate rock · Karst $\cdot$ Water resources $\cdot$ Global mapping $\cdot$ Geographic information systems

This article describes a project supported by the International Association of Hydrogeologists (IAH) Commission on Karst Hydrogeology (https:// karst.iah.org/)

Nico Goldscheider

nico.goldscheider@kit.edu

$\triangle$ Zhao Chen

chen.zhao@gmx.de

1 Institute of Applied Geosciences, Division of Hydrogeology, Karlsruhe Institute of Technology (KIT), Kaiserstr. 12, 76131 Karlsruhe, Germany

2 Instituto do Carste, Rua Barcelona 240/302, Belo Horizonte, MG 30360-260, Brazil

3 HydroSciences, University of Montpellier, UMR5569 - CC0057, 163 rue Auguste Broussonet, 34090 Montpellier, France

4 Federal Institute for Geosciences and Natural Resources, Wilhelmstr. 25-30, 13593 Berlin, Germany

5 Retired from Trinity College Dublin, Moheraroon, Kilfenora, Co. Clare, Ireland
6 Institute for Geology, Center for Earth System Research and Sustainability (CEN), University of Hamburg, Bundesstr. 55, 20146 Hamburg, Germany

7 Key Laboratory of Karst Dynamics, Institute of Karst Geology, Guilin 541004, China

8 Leibniz Centre for Tropical Marine Research (ZMT), Fahrenheitstr. 6, 28359 Bremen, Germany

9 Institute of Geosciences, University of Kiel, Ludewig-Meyn-Str. 10, 24118 Kiel, Germany

10 Department of Hydrogeology, Centre for Karst Hydrogeology, University of Belgrade, Faculty of Mining \& Geology, Djusina 7, Belgrade 11000, Serbia

11 National Cave and Karst Research Institute, 400-1 Cascades Avenue, Carlsbad, NM 88220-6215, USA 


\section{Introduction}

Karst regions are among the most diverse hydrogeological environments on our planet and they are strongly linked to processes in the atmosphere, hydrosphere and biosphere, and to human history and development. They offer a variety of valuable natural resources such as freshwater from aquifers for human consumption, agricultural irrigation and groundwater-dependent ecosystems (Bakalowicz 2005); thermal and mineral water for bathing and geothermal energy production (Goldscheider et al. 2010); soils providing the basis for natural vegetation and food production (Feeser and O'Connell 2009); high biodiversity both at the land surface and underground (Clements et al. 2006; Sket 1999); unique landscapes and caves with high cultural, historical and recreational value (Goldscheider 2019); and carbonate rock that is extensively used as building material and for industrial purposes, mainly cement production, which in turn impacts the other natural resources of karst aquifers and ecosystems (Hobbs and Gunn 1998). Carbonate rocks are part of the global carbon cycle and are involved in manifold biogeochemical processes (Hartmann et al. 2009). The process of karstification acts as a natural sink for carbon dioxide $\left(\mathrm{CO}_{2}\right)$, at least on short time scales, and therefore helps to mitigate environmental acidification and provides a transient negative feedback on global warming (Liu et al. 2010).

Karst aquifers form by the chemical dissolution of soluble rock. Carbonate rocks such as limestone and dolomite, are the most important karstifiable rocks, but karstification also occurs in evaporite rocks such as gypsum, and occasionally in other rock types. In the case of carbonate rocks, $\mathrm{CO}_{2}$ from the atmosphere and/or from the soil zone plays a key role in karstification (Ford and Williams 2007).

Infiltrating rainwater or meltwater containing $\mathrm{CO}_{2}$ from the atmosphere or soil zone enters the subsurface, circulates in the fissures and fractures of the carbonate rock, and results in karstification (although deep-seated sources of solutional aggressiveness can also be significant). Karstification is a selfamplifying and selective process; higher through-flow and chemical dissolution occurs along the largest open fractures, leading to accelerated growth of their apertures and eventually to the formation of hierarchically connected networks of solutionally widened fractures, conduits and caves, which typically converge into a single master conduit drained by one large spring (Dreybrodt 1990). Indeed, most of the largest springs on our planet are karst springs (Kresic and Stevanovic 2010). Karst processes are generally rapid, so that underground drainage fits new base levels related to morphological changes and/or tectonic movements, creating complex drainage structures in multiphased karst aquifers. The conduits are embedded in, and hydraulically interact with, the surrounding matrix of less karstified, fissured carbonate rock (Bailly-Comte et al. 2010).
Because of their unique hydraulic structure, karst aquifers often display rapid and marked responses to hydrometeorological events in terms of water level in the aquifer, flow velocities in the conduit system, spring discharge, and water quality (Hartmann et al. 2014). Karst groundwater resources are particularly vulnerable to contamination, because chemical and microbial pollutants can easily enter the subsurface and spread rapidly in the conduit network without sufficient attenuation. Furthermore, karst systems are often connected over large areas, thus requiring transboundary water resource management concepts. For all these reasons, karst aquifers are particularly challenging to explore, exploit, protect, and manage sustainably in terms of water availability and quality (Goldscheider and Drew 2007).

According to an often-cited estimation by Ford and Williams (2007), about $25 \%$ of the global population is partly or entirely supplied by freshwater from karst. More recently, Stevanovic (2019) estimated that the number of karst water consumers in 2016 was 678 million or $9.2 \%$ of the world's population. The study by Stevanovic is based on a more detailed global database and a more elaborate analysis. Therefore, this recent estimation is probably more realistic.

Against this background, the World Karst Aquifer Mapping project was established in 2012. The general workflow, the legend and a draft karst aquifer map of Europe was published by Chen et al. (2017a). The final World Karst Aquifer Map (WOKAM) and geodatabase was completed in 2017 (Chen et al. 2017b). The present paper is the first detailed statistical evaluation of WOKAM at global scale, focusing on carbonate rock aquifers, because they are far more relevant in terms of water resources and regionally far more widespread than evaporite rocks. The main goals are to:

1. Evaluate the geographic distribution of karst globally, by continent, and in the largest countries in terms of surface area and population.

2. Quantify the distribution of karst in plains, hills and mountains, and evaluate the occurrence of coastal karst, globally and in selected regions.

3. Assess the distribution of karst in different climatic zones, ranging from tropical to polar, and in different precipitation regimes, ranging from arid to very humid.

4. Analyze the relations between karst and population by quantifying the number and percentage of people living on karst, globally and for all continents.

All analyses presented in this paper focus entirely on carbonate rocks, because they are the most important rock type in terms of karst hydrogeology. The underlying WOKAM map and database, however, also includes evaporitic rocks. During their long and often complex geologic and hydro-climatic history, most carbonate rocks have experienced at least some 
degree of karstification; therefore, it is safe to assume that all carbonate rocks are karstified unless proven otherwise. Thus, more precisely, this paper refers to carbonate rocks as representing potential karst aquifers.

The World Karst Aquifer Map offers many more opportunities for a wide range of scientific and practical analyses and evaluations at different scales, some of which were highlighted in the first paragraph of the introduction. WOKAM is part of the World-wide Hydrogeological Mapping and Assessment Programme (WHYMAP) under the umbrella of the UNESCO International Hydrological Programme (UNESCO-IHP). The conclusions in this paper highlight possible fields of application of this global map and database, which are also available in the online dataset of WHYMAP WOKAM (BGR 2019).

\section{Materials and methods}

For the analyses, the data and information from the WOKAM digital map and database (Chen et al. 2017b) were combined with a wide range of publicly available global online datasets. All analyses were done using Arc GIS Desktop by ESRI (version 10.4.1).

As WOKAM is part of the World-wide Hydrogeological Mapping and Assessment Programme (WHYMAP), the same data sets/shapefiles concerning continent boundaries, state boundaries, ice sheets, and lakes were used than for all other products of the WHYMAP series. These data were obtained from the WHYMAP team at BGR and are essentially based on data from the online collection of data and maps for ArcGIS (ArcGIS online, ESRI) and from the UN Geospatial Information Section. National population estimations come from the United Nations Population Prospects 2017 Revision (UN 2017). Global landforms were obtained from Sayre et al. (2014). The global climatic zones come from an updated version of the conventional Köppen-Geiger climate classification at 1-km resolution (Beck et al. 2018). Global population densities were obtained from "Center for International Earth Science Information Network" (CIESIN) and "Centro Internacional de Agricultura Tropical" (CIAT) (CIESIN and CIAT 2005a, b). The coastline was obtained from Natural Earth Data. Global precipitation data were taken from Meyer-Christopher et al. (2015). The analyses focus on the continental ice-free land surface. This excludes Antarctica, as it is mostly covered by glacier ice, but includes the ice-free parts of Greenland, as a part of North America.

\section{Essential concepts and principal contents of the World Karst Aquifer Map}

Figure 1 shows a strongly generalized and downscaled version of WOKAM, while Fig. 2 shows an enlarged section of the map in order to better illustrate the concept and degree of detail of the original full-scale map. WOKAM is based on the observation that karst aquifers typically develop in carbonate rocks containing more than $75 \%$ of carbonate minerals, and in evaporite rocks (Ford and Williams 2007). Although the actual degree of karstification and the aquifer properties depend on several geological, geomorphological, geochemical and hydro-climatological aspects, it is a safe and pragmatic approach to assume that all outcrops of such rocks are karstified at least to some degree. Therefore, all exposed karstifiable carbonate and evaporite rocks were mapped as potential karst aquifers; however, the analyses in the present paper focus entirely on carbonate rocks. Generalization was done at a working scale of 1:10 million. An inherent problem in the generalization of maps is the existence of polygons that are too small or complex in shape to be displayed. To overcome this problem, carbonate (and evaporite) areas were subdivided into "continuous" and "discontinuous", based on the area's share of the respective rock type (Chen et al. 2017a). Wherever possible, the mapping unit continuous was applied, because it is readily understood. Polygons classified as continuous often include small patches of nonkarst surfaces. By comparing the original with the generalized polygons, it turned out that the percentage of carbonate rocks was generally $>65 \%$. For areas that contain highly scattered or ramified outcrops, the mapping unit discontinuous was introduced. This approach was validated in several regions, and it turned out that the limits of 15 and $65 \%$ result in a hydrogeologically meaningful generalization. Therefore, areas with more than $65 \%$ of carbonate (or evaporite) rock were classified as continuous on WOKAM, whereas areas between 15 and $65 \%$ were classified as discontinuous. Areas containing more than $15 \%$ of each rock type (carbonate and evaporite) were mapped as mixed karst. The example map in Fig. 2 shows a region where all of these mapping units are present. Zones where exposed karstifiable rocks plunge under adjacent overlying formations - typically stratigraphically higher clastic sedimentary formations - are highlighted by a line of triangles that points in the direction of nonexposed carbonate or evaporite rocks. These lines indicate the location of nonexposed, deep and confined aquifers which are potential resources for freshwater or, with increasing depth, thermal and mineral water. The detailed map in Fig. 2 shows several of such contacts, e.g. the southern margin of the Edwards Aquifer (Texas, USA) where exposed carbonate rocks ("recharge zone") plunge under overlying clastic sedimentary formations ("artesian zone"). However, these nonexposed potential karst aquifers are not spatially delineated in WOKAM, because this would require three-dimensional (3D) geological information that was not available at a global scale. Therefore, all following statistical analyses referring to the spatial distribution of karst are restricted to exposed carbonate rocks. Groundwater resources in exposed carbonate rocks are more vulnerable to contamination resulting from intense agriculture and other 
human activities than those in nonexposed carbonate rocks (Goldscheider 2005). Therefore, a map of exposed carbonate rocks is particularly useful and relevant for land-use planning in terms of groundwater protection.

The Global Lithological Map (GLiM) was an important data source for WOKAM (Hartmann and Moosdorf 2012), but many other regional maps at different scales were also used, according to a well-defined and consistent workflow that was described by Chen et al. (2017a). Evaluation by an international network of regional experts was an important part of this process.

The full-scale WOKAM map and database also include 201 selected karst water sources, including 162 continental freshwater springs, 16 submarine springs, 8 thermal springs and 15 water abstraction structures, as well as 93 selected cave systems. The detailed map section in Fig. 2 also illustrates how these karst water sources and caves are shown on the full-scale map. Tables 1 and 2 present details. The selection criteria for springs and caves include regional relevance, size and discharge (details in Chen et al. 2017a). The map in Fig. 3 and the associated Table 3 present a small selection of the largest and most important karst springs on all continents, selected on the basis of discharge and on regional distribution and significance. Recently, a World Karst Spring Hydrograph Database (WOKAS) has been prepared (Olarinoye et al. 2020), complementing the data included in the WOKAM database. WOKAM also indicates permafrost boundaries (areal percentage $>50 \%$ ), because karst development and karst aquifer behavior is very different and limited under permafrost conditions (Ford 1987).

\section{Global and regional distribution of carbonate rocks}

According to the analysis, $9.4 \%$ of the global ice-free land surface consists of continuous carbonate rocks (CC) and $5.8 \%$ are occupied by discontinuous carbonate rocks (DC) or carbonate rocks mixed with evaporites. This means that $15.2 \%$ or 20.3 million $\mathrm{km}^{2}$ of the land surface are characterized by the presence of carbonate rocks, representing potential karst aquifers that have surface or near-surface exposure.

Carbonate rocks are present on all continents (Table 4). The largest absolute surface area is found on the largest continent, Asia, where 8.35 million $\mathrm{km}^{2}$ continuous, discontinuous or mixed carbonate rocks are present, corresponding to $18.6 \%$ of Asia's land surface. The highest percentage of karst is present in Europe, where $15.2 \%$ of continuous and $6.6 \%$ of discontinuous and mixed carbonate rocks were mapped, resulting in a total area share of $21.8 \%$ and an absolute area of 2.17 million $\mathrm{km}^{2}$. Substantial amounts of carbonate rocks are also found in North America (19.6\% or 4.43 million $\mathrm{km}^{2}$ ) and Africa ( $13.5 \%$ or 4.05 million $\mathrm{km}^{2}$ ), whereas smaller percentages of carbonate rocks are present in Australia and Oceania
(6.2\% or 0.50 million $\mathrm{km}^{2}$ ) and South America (4.3\% or 0.77 million $\mathrm{km}^{2}$ ).

As a next step, the distribution of carbonate rocks in the 20 largest countries in terms of surface area (A1-A20) and population (P1-P20) was analysed (Table 5). According to this analysis, China and Russia are the countries with the largest and nearly identical absolute karst surface areas, 2.55 and 2.51 million $\mathrm{km}^{2}$, respectively, corresponding to 26.5 and $14.7 \%$ of the land surface. Indeed, among the ten largest countries (A1-A10), China has the largest area percentage of karst, but USA and Canada also have high percentages of carbonate rock outcrops (21.3 and 16.6\%, respectively). Among the other countries on this list, Iran has the largest area share (54.3\%), followed by Egypt (45.2\%), Nigeria (30.5\%), Ethiopia (29.9\%) and Vietnam (27.2\%). At the other end of the scale, Sudan, Chad and Japan have no or very little identified karst on WOKAM. Despite the low percentage of carbonate rocks in Japan $(0.1 \%)$, this country has some well-developed karst such as the Akiyoshi Plateau with more than 400 caves, and several large karst springs. This example illustrates that low percentage values do not mean absence of locally significant karst landscapes and aquifers.

The previous WOKAM paper (Chen et al. 2017a) included a similar table for all European countries, some of which have even higher percentages of total carbonate rock areas such as Montenegro (80.1\%), Bosnia and Herzegovina (60.5\%), Slovenia $(49.5 \%)$ and France $(35.0 \%)$. France also has the highest absolute carbonate rock surface area $(0.19$ million $\mathrm{km}^{2}$ ) of all European countries with the exception of Russia, which extends over Europe and Asia. The European part of Russia alone has more carbonate rock surface areas ( 0.45 million $\mathrm{km}^{2}$ ) than any other European country.

\section{Karst in plains, hills and mountains, and coastal karst}

The occurrence of carbonate rocks/potential karst aquifers in different types of landforms was also analysed. The simplest and most pragmatic classification of landforms at global scale is into plains, hills, and mountains. These three landforms are classified using slope class and relative relief, which are calculated based on a global digital elevation model with 250-m resolution (Sayre et al. 2014). According to the analysis, $31.1 \%$ of all karst occurs in plains, $28.1 \%$ in hills and $40.8 \%$ in mountains (Table 6).

In Australia and Oceania, 55.3\% of all mapped karst occurs in plains, with the Nullarbor Plain in South Australia as the most prominent example. Very large karst plains also occur on the North American continent, where $44.2 \%$ of all karst forms plains such as the extensive lowland karst areas in the eastern and central parts of Canada, the USA, and Mexico. Figure 2 shows two prime examples of karst plains: Florida (USA), and the Yucatan peninsula in Mexico. 


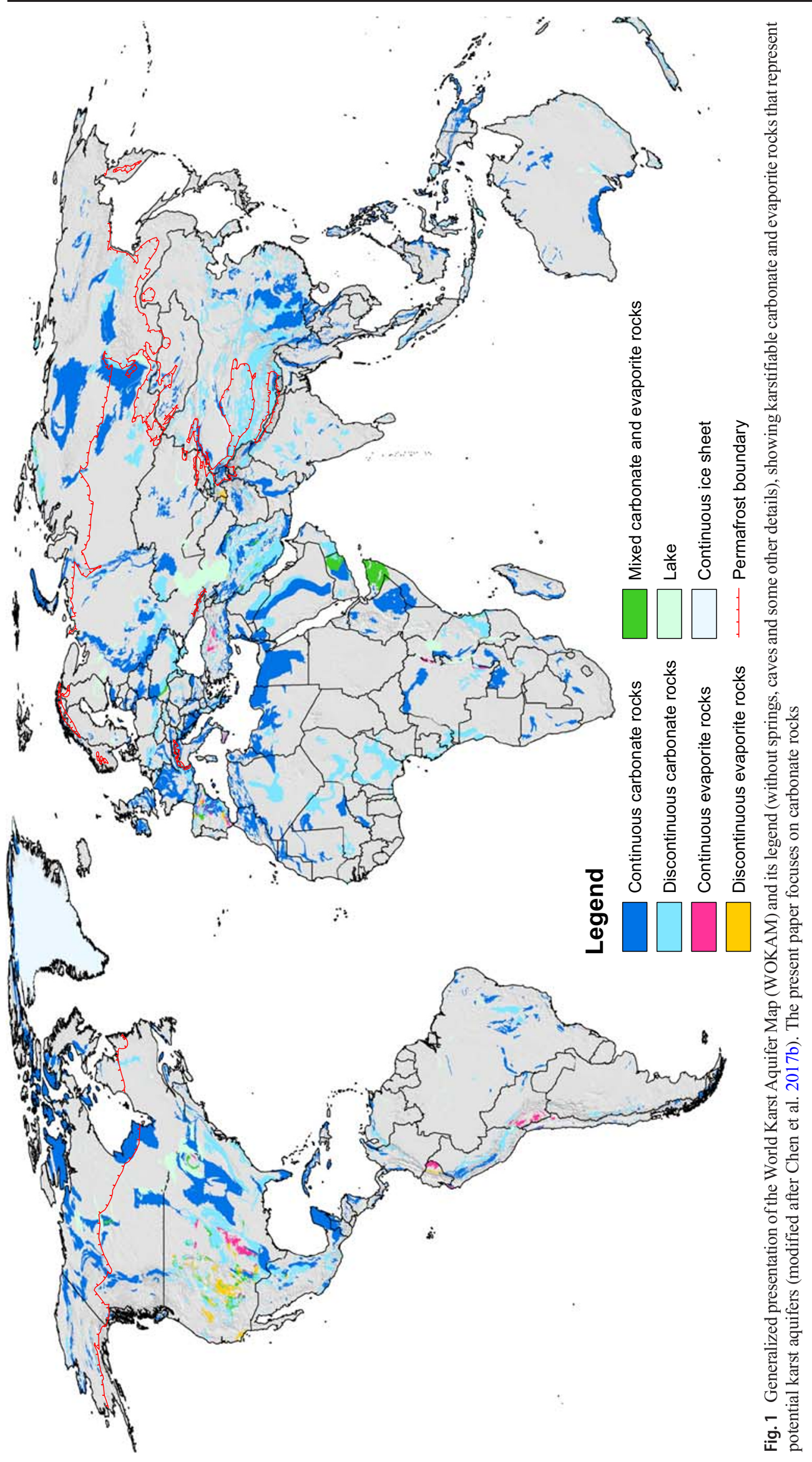


Fig. 2 Detail of the full-scale World Karst Aquifer Map for the southern USA and Central America, illustrating essential concepts and contents of WOKAM. This excerpt includes all mapping units of WOKAM (i.e., all types of continuous, discontinuous and mixed carbonate and evaporite rocks), boundaries between exposed and nonexposed karst, as well as selected karst springs and caves (details see Tables 1 and 2). The Edwards Aquifer in Texas is a prime example for an exposed karst aquifer plunging under younger clastic sedimentary rocks forming a deep and confined aquifer. Florida and the Yucatan Peninsula are among the world's largest coastal and lowland karst regions

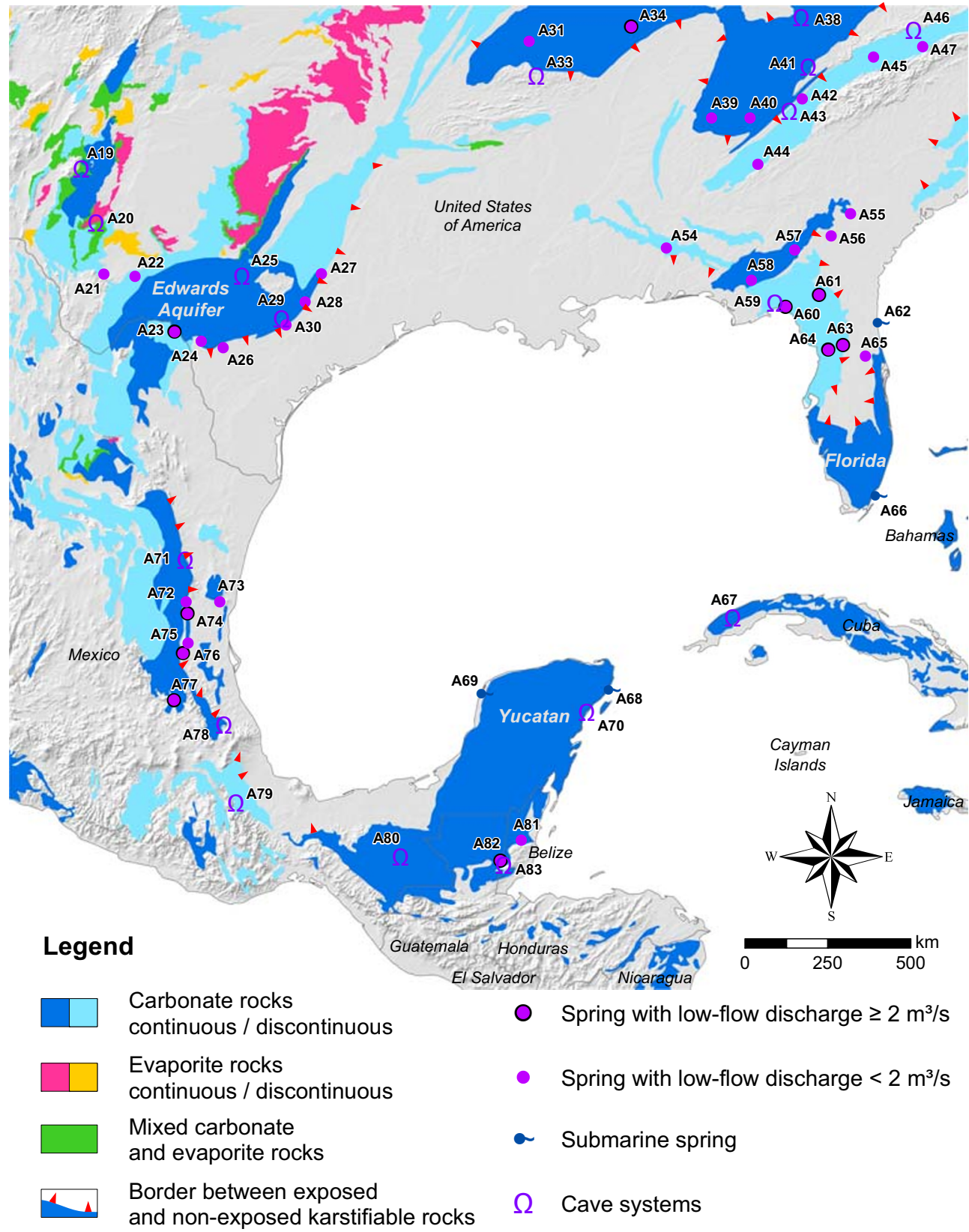

In South America, more than two thirds (68.5\%) of all karst occurs in mountainous areas, such as the spectacular alpine karst systems in the Peruvian Andes. Asia also has a high percentage of mountain karst, 59.6\%, including the mountainous karst areas in Iran, southern China and Southeast Asia. Although the percentage of mountain karst is a bit lower in Europe (28.9\%), mountainous karst aquifers are very important freshwater supplies for many European countries and cities such as Vienna in Austria and Rome in Italy (Kresic and Stevanovic 2010).

As a large proportion of global population lives in coastal areas, coastal aquifers are particularly important freshwater supplies. At the same time, these aquifers are particularly sensitive to natural seawater intrusion (Arfib et al. 2007; Pinault et al. 2004), exacerbated by overexploitation resulting in the upconing of saline water. For the analysis on coastal karst, a coastline map at a 1:10 million scale from WHYMAP was used and a $5-\mathrm{km}$ buffer (corresponding to $0.2 \mathrm{~mm}$ on the 1:40 million map) was applied to identify coastal karst. According to the analysis, the global total length of coastal carbonate rocksper karst is about $151,400 \mathrm{~km}$, about $15.7 \%$ of the total global coastline apart from Antarctica (Table 7). It is clear the obtained absolute length depends on the scale of the coastline map, while the percentage is assumed to be a relatively reliable estimation. According to the analysis, about one quarter of these coastal carbonate rocks occur in the Canadian 
Arctic and Hudson Bay, with a total length of $37,167 \mathrm{~km}$, although scattered on several islands and sections of the continental coastline, mostly far from human population and with largely unknown karst and aquifer properties. Important examples of well-known coastal karst include the Dinaric Karst along the Adriatic Coast $(2,707 \mathrm{~km})$, Florida $(2,220 \mathrm{~km})$, the

Table 1 Summary of selected springs in the example area shown on the map in Fig. 2. Quantitative estimations for low-flow and high-flow discharge $\left(\mathrm{m}^{3} / \mathrm{s}\right)$ are indicated; $n . d$. no data available

\begin{tabular}{|c|c|c|c|}
\hline \multirow[t]{2}{*}{ ID } & \multirow[t]{2}{*}{ Name } & \multicolumn{2}{|l|}{ Discharge } \\
\hline & & Low $\left[\mathrm{m}^{3} / \mathrm{s}\right]$ & $\operatorname{High}\left[\mathrm{m}^{3} / \mathrm{s}\right]$ \\
\hline A 21 & San Solomon Springs & 0.9 & 2 \\
\hline A 22 & Comanche Springs & 0.3 & 3 \\
\hline A23 & Goodenough Springs & 4.1 & n.d. \\
\hline A24 & Las Moras Springs & 0.3 & 3 \\
\hline A26 & Leona Springs & 0.3 & 3 \\
\hline A27 & Salado Springs & 0.03 & 0.3 \\
\hline A28 & Barton Springs & 0.4 & 3.5 \\
\hline A 30 & Comal Springs & 0.01 & 14 \\
\hline A31 & Roaring River Spring & 0.2 & 5 \\
\hline A34 & Big Spring & 6.7 & 37 \\
\hline A39 & Tuscumbia Spring & 0.2 & 0.9 \\
\hline $\mathrm{A} 40$ & Huntsville Spring & 0.01 & 0.3 \\
\hline A 42 & Cave Springs & 0.6 & 1.2 \\
\hline A 44 & Coldwater Spring & 0.2 & n.d. \\
\hline A 45 & Buffalo Spring & 0.3 & 0.7 \\
\hline A47 & Morrell Spring & 0.3 & 0.9 \\
\hline A54 & Gilmore Spring & 0.2 & n.d. \\
\hline A55 & Rock Springs & 0.1 & n.d. \\
\hline A56 & Osewichee Spring & 0.1 & 0.5 \\
\hline A57 & Radium Spring & 0.5 & 4 \\
\hline A58 & Jackson Blue Spring & 1.6 & 8 \\
\hline A 60 & Nutall River Rise & 10.2 & 10.2 \\
\hline A61 & Alapaha River Rise & 14.4 & 20 \\
\hline A62 & Crescent Beach & 40 & n.d. \\
\hline A63 & Silver Springs Main & 15.3 & 37 \\
\hline A64 & Rainbow Spring & 13.8 & 35 \\
\hline A65 & Volusia Blue Spring & 1.8 & 6 \\
\hline A66 & Biscayne Bay & n.d. & n.d. \\
\hline A68 & Puerto Morelos & n.d. & n.d. \\
\hline A69 & Celestun Lagoon & n.d. & n.d. \\
\hline A72 & Nacimiento de Rio Frio & 0.6 & 515 \\
\hline A73 & El Zacaton & 0.1 & 5 \\
\hline A74 & Nacimiento del Rio Mante & 8 & 343 \\
\hline A75 & Nacimiento del Rio Choy & 1.5 & 100 \\
\hline A76 & Nacimiento del Rio Coy & 13 & 236 \\
\hline A77 & Grutas de Tolantongo & 3.4 & n.d. \\
\hline A81 & Boiling Hole & 0.7 & 7 \\
\hline A 82 & Chiquibul Spring & 2 & n.d. \\
\hline
\end{tabular}

Yucatan Peninsula in Mexico $(1,807 \mathrm{~km})$ (the latter two are shown in Fig. 2), the Nullarbor Plain in South Australia $(1,507 \mathrm{~km})$ and the Mediterranean coastline of Libya and Egypt $(982 \mathrm{~km})$. The thousands of small islands of Micronesia and other groups of carbonate islands would require a more detailed analysis.

\section{Karst and climate}

Carbonate rocks are present in all climatic zones, and the type and degree of karst development is influenced by the climatic conditions (Ford and Williams 2007). The intensity of karst processes can be expressed by the denudation rate, i.e., millimeters of carbonate rock that are dissolved per thousand years $(\mathrm{mm} / \mathrm{kyr})$. Field observations from all over the planet, complemented by theoretical and experimental work, have shown that the denudation rate depends on the climatic water balance, i.e., precipitation $(P)$ minus actual evapotranspiration (ETa). Denudation rates often range between 10 and $100 \mathrm{~mm} /$ kyr but can be close to zero under extremely dry conditions and exceed $200 \mathrm{~mm} / \mathrm{kyr}$ under extremely humid conditions (Gabrovsek 2009). However, as climate changes on different time scales, karstified carbonate rocks can also be encountered in zones where the present climatic conditions do not favor intense karst development: for example, the karst aquifers in Saudi Arabia and other arid regions, which are characterized by high rates of water use but very limited or no present-day recharge ("fossil groundwater"), resulting in chronic

Table 2 Summary of selected caves in the southern USA and Central America, shown on the map in Fig. 2. Caves are characterized by length $(\mathrm{km})$ and depth $(\mathrm{m})$. (data from Gulden 2020). n.d. no data available

\begin{tabular}{llll}
\hline ID & Name & Length [km] & Depth [m] \\
\hline A19 & Fort Stanton Cave & 64.6 & 134 \\
A20 & Lechuguilla Cave & 242.0 & 484 \\
A25 & Powell's Cave System & 26.1 & 24 \\
A29 & Honey Creek Cave & 33.3 & 38 \\
A33 & Fitton (Beauty) Cave & 28.2 & 95 \\
A38 & Mammoth Cave System & 667.9 & 124 \\
A41 & Blue Spring Cave & 64.4 & 94 \\
A43 & Ellisons Cave & 19.5 & 324 \\
A46 & Omega System & 47.4 & 385 \\
A59 & Wakulla-Leon Sinks Cave System & 54.3 & 107 \\
A67 & Gran Caverna de Palmarito & 54.0 & n.d. \\
A70 & Sac Actun Cave System & 372.0 & 119 \\
A71 & Purificacion Cave System & 93.8 & 953 \\
A78 & Cuetzalan - Atepolihuit Cave System & 37.7 & 658 \\
A79 & Huautla Cave System & 89.0 & 1,560 \\
A80 & Soconusco Cave System & 23.9 & 513 \\
A83 & Chiquibul Cave System & 39.0 & 160 \\
\hline
\end{tabular}




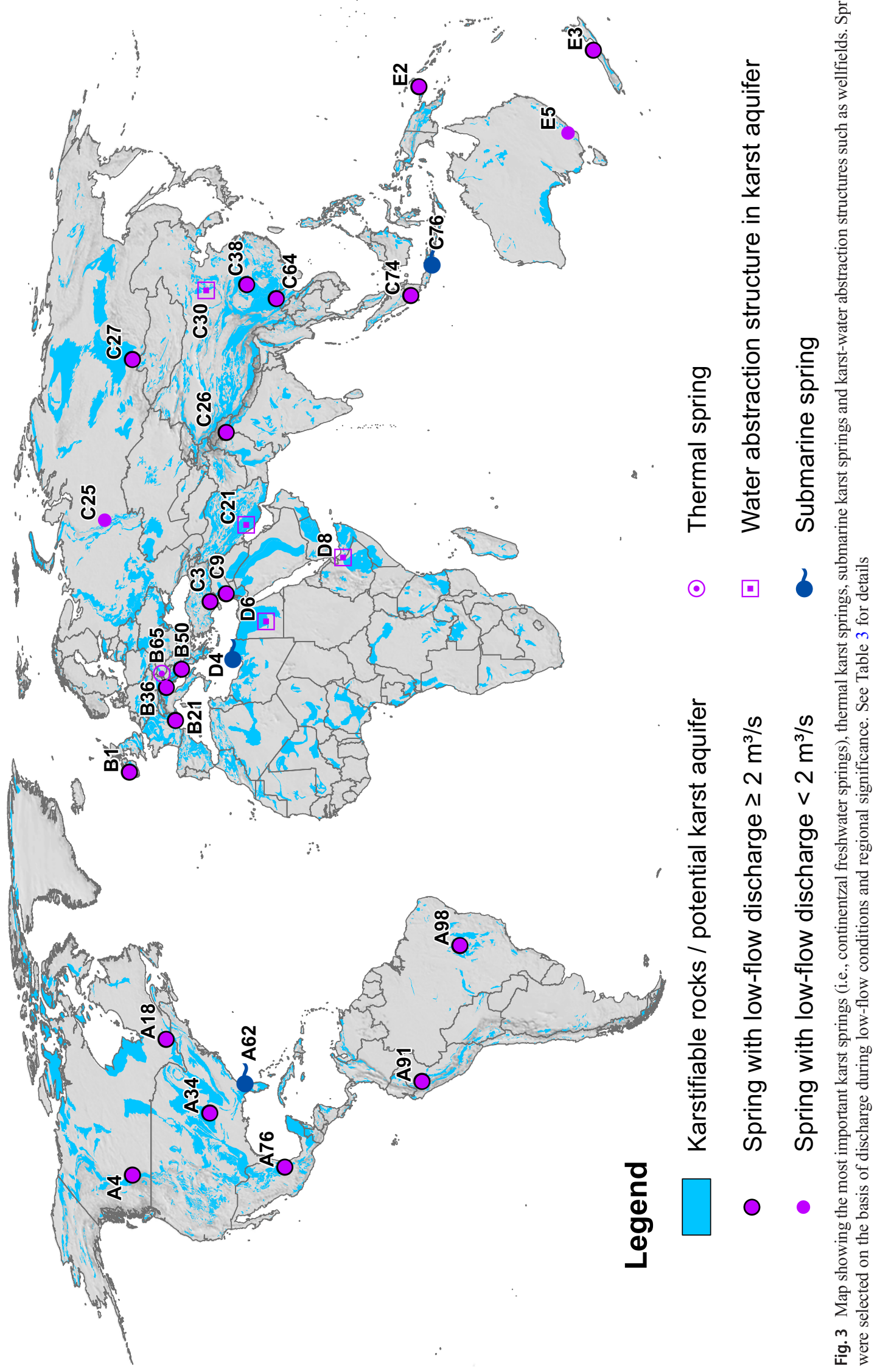


Table 3 Summary of the selected karst water sources shown on the map in Fig. 3 grouped as Continental freshwater springs and Thermal karst springs, Submarine karst springs and Water abstraction structures
Table 4 Statistics of carbonate rock areas/potential karst aquifers on all continents and globally. North America includes the icefree parts of Greenland

\begin{tabular}{|c|c|c|c|c|}
\hline \multirow[t]{2}{*}{ ID } & \multirow[t]{2}{*}{ Name } & \multirow[t]{2}{*}{ Country, region } & \multicolumn{2}{|l|}{ Discharge } \\
\hline & & & Low $\left[\mathrm{m}^{3} / \mathrm{s}\right]$ & $\operatorname{High}\left[\mathrm{m}^{3} / \mathrm{s}\right]$ \\
\hline \multicolumn{5}{|c|}{ Continental freshwater springs } \\
\hline A4 & Maligne & Canada, Alberta & 15.2 & 40 \\
\hline A18 & Ottawa River Caves & Canada, Ontario/Quebec & 10 & n.d. \\
\hline A34 & Big Spring & USA, Missouri & 7 & 37 \\
\hline A76 & Nacimiento del Rio Coy & Mexico & 13.0 & 236 \\
\hline A91 & Negro River Spring & Peru & 15.0 & n.d. \\
\hline A98 & São Bernardo & Brazil, Goiás & 5 & n.d. \\
\hline B1 & Cong Springs & Ireland & 5 & n.d. \\
\hline $\mathrm{B} 21$ & Fontaine de Vaucluse & France & 4.0 & 150 \\
\hline B36 & Timavo & Italy & 30.2 & n.d. \\
\hline $\mathrm{B} 50$ & Ombla & Croatia & 4 & 138 \\
\hline $\mathrm{C} 3$ & Dumanli & Turkey & 38 & 50 \\
\hline C9 & Figeh Spring & Syria & 2.5 & 13 \\
\hline $\mathrm{C} 25$ & Bobrovaya & Russia, Permskij Kraj & 1.5 & 3.0 \\
\hline $\mathrm{C} 26$ & Panzethnag & India, Kashmir & 2.2 & 3.0 \\
\hline $\mathrm{C} 27$ & Bolshaja Iret & Russia, Irkutskaja Oblast & 12 & n.d. \\
\hline $\mathrm{C} 38$ & Chexinwan & China, Hunan & 32.8 & n.d. \\
\hline $\mathrm{C} 64$ & Zhongzhai & China, Yunnan & 37.2 & n.d. \\
\hline $\mathrm{C} 74$ & Gua Besar & Indonesia & 2.2 & n.d. \\
\hline $\mathrm{E} 2$ & Tobio & Papua New Guinea & 85 & 115 \\
\hline E3 & Te Waikoropupu Spring & New Zealand & 5.8 & 21 \\
\hline E5 & Blue Waterholes & Australia, New South Wales & 0.2 & 2.2 \\
\hline \multicolumn{5}{|c|}{ Submarine karst springs } \\
\hline A62 & Crescent Beach & USA, Florida & 40 & n.d. \\
\hline $\mathrm{C} 76$ & Pantai Ngrenehan & Indonesia & 8 & n.d. \\
\hline D4 & Ayn Zayanah & Libya & 5 & n.d. \\
\hline \multicolumn{5}{|c|}{ Thermal karst springs } \\
\hline B65 & Hévíz Lake Spring & Hungary & 0.3 & 0.6 \\
\hline \multicolumn{5}{|c|}{ Water abstraction structures in karst aquifers ${ }^{\mathrm{a}}$} \\
\hline $\mathrm{C} 21$ & Masarm & Iran & 1.7 & n.d. \\
\hline $\mathrm{C} 30$ & Liulinquan & China, Shanxi & 2.8 & n.d. \\
\hline D6 & Ain El Gabal & Egypt & 0.5 & n.d. \\
\hline D8 & Borama & Somalia & 0.2 & 0.5 \\
\hline
\end{tabular}

${ }^{a}$ Includes estimations for low-flow and high-flow discharge $\left(\mathrm{m}^{3} / \mathrm{s}\right)$ n.d. no data

\begin{tabular}{|c|c|c|c|c|c|c|c|}
\hline \multicolumn{2}{|l|}{ Continent } & \multicolumn{6}{|c|}{ Carbonate rock areas } \\
\hline \multirow[t]{2}{*}{ Name } & \multirow[t]{2}{*}{$1,000 \mathrm{~km}^{2}$} & \multicolumn{2}{|l|}{$\mathrm{CC}$} & \multicolumn{2}{|c|}{ DC and mixed } & \multicolumn{2}{|l|}{ total } \\
\hline & & $1,000 \mathrm{~km}^{2}$ & $\%$ & $1,000 \mathrm{~km}^{2}$ & $\%$ & $1,000 \mathrm{~km}^{2}$ & $\%$ \\
\hline Europe & 9,944 & 1,510 & 15.2 & 657 & 6.6 & 2,167 & 21.8 \\
\hline Africa & 30,068 & 2,496 & 8.3 & 1,558 & 5.2 & 4,054 & 13.5 \\
\hline Asia & 44,928 & 4,625 & 10.3 & 3,723 & 8.3 & 8,348 & 18.6 \\
\hline Australia \& Oceania & 8,149 & 374 & 4.6 & 129 & 1.6 & 503 & 6.2 \\
\hline North America & 22,579 & 3,132 & 13.9 & 1,303 & 5.8 & 4,435 & 19.6 \\
\hline South America & 17,798 & 443 & 2.5 & 324 & 1.8 & 767 & 4.3 \\
\hline World & 133,467 & 12,579 & 9.4 & 7,695 & 5.8 & 20,274 & 15.2 \\
\hline
\end{tabular}

$\mathrm{CC}=$ continuous carbonate rocks; $\mathrm{DC}$ and mixed $=$ discontinuous carbonate rocks and carbonate rocks mixed with evaporites 
Table 5 Distribution of carbonate rocks in the 20 largest countries in terms of surface area $(A 1-A 20)$ and population $(P 1-P 20)$, ordered by decreasing surface area

\begin{tabular}{|c|c|c|c|c|c|c|c|c|c|c|}
\hline \multicolumn{5}{|l|}{ Country } & \multicolumn{6}{|c|}{ Carbonate rock areas } \\
\hline \multirow[t]{2}{*}{ Name } & \multirow[t]{2}{*}{ Rank } & & \multirow[t]{2}{*}{$1,000 \mathrm{~km}^{2}$} & \multirow[t]{2}{*}{ Population (million) } & \multicolumn{2}{|l|}{$\mathrm{CC}$} & \multicolumn{2}{|c|}{ DC and mixed } & \multicolumn{2}{|l|}{ total } \\
\hline & & & & & $1,000 \mathrm{~km}^{2}$ & $\%$ & $1,000 \mathrm{~km}^{2}$ & $\%$ & $1,000 \mathrm{~km}^{2}$ & $\%$ \\
\hline Russia & A1 & P9 & 17,098 & 143.9 & 1,858 & 10.9 & 655 & 3.8 & 2,513 & 14.7 \\
\hline Canada & $\mathrm{A} 2$ & - & 9,971 & 35.9 & 1,610 & 16.1 & 41 & 0.4 & 1,651 & 16.6 \\
\hline USA & A3 & P3 & 9,629 & 319.9 & 981 & 10.2 & 1,072 & 11.1 & 2,052 & 21.3 \\
\hline China & A4 & $\mathrm{P} 1$ & 9,597 & $1,404.9$ & 894 & 9.3 & 1,651 & 17.2 & 2,546 & 26.5 \\
\hline Brazil & A5 & P5 & 8,515 & 206.0 & 219 & 2.6 & 93 & 1.1 & 312 & 3.7 \\
\hline Australia & A6 & - & 7,741 & 23.8 & 319 & 4.1 & 72 & 0.9 & 391 & 5.0 \\
\hline India & A7 & $\mathrm{P} 2$ & 3,287 & $1,309.1$ & 77 & 2.3 & 213 & 6.5 & 290 & 8.8 \\
\hline Argentina & A8 & - & 2,780 & 43.4 & 8.2 & 0.3 & 37 & 1.3 & 45 & 1.6 \\
\hline Kazakhstan & A9 & - & 2,725 & 17.7 & 185 & 6.8 & 91 & 3.4 & 277 & 10.2 \\
\hline Algeria & A10 & - & 2,382 & 39.9 & 176 & 7.4 & 192 & 8.1 & 368 & 15.4 \\
\hline DR Congo & A11 & $\mathrm{P} 17$ & 2,345 & 76.2 & 145 & 6.2 & 73 & 3.1 & 218 & 9.3 \\
\hline Saudi-Arabia & A12 & - & 2,150 & 31.6 & 344 & 16.0 & 150 & 7.0 & 494 & 23.0 \\
\hline Mexico & A13 & P10 & 1,958 & 125.9 & 310 & 15.8 & 189 & 9.6 & 499 & 25.5 \\
\hline Indonesia & A14 & $\mathrm{P} 4$ & 1,905 & 258.2 & 178 & 9.4 & 125 & 6.6 & 304 & 15.9 \\
\hline Sudan & A15 & - & 1,861 & 38.6 & 0.0 & 0.0 & 0.0 & 0.0 & 0.0 & 0.0 \\
\hline Libya & A16 & - & 1,760 & 6.2 & 351 & 19.9 & 38 & 2.1 & 388 & 22.1 \\
\hline Iran & A17 & P18 & 1,648 & 79.4 & 352 & 21.4 & 543 & 33.0 & 895 & 54.3 \\
\hline Mongolia & A18 & - & 1,564 & 3.0 & 69 & 4.4 & 1.0 & 0.1 & 70 & 4.5 \\
\hline Peru & A19 & - & 1,285 & 31.4 & 89 & 6.9 & 109 & 8.5 & 198 & 15.4 \\
\hline Chad & $\mathrm{A} 20$ & - & 1,284 & 14.0 & 0.0 & 0.0 & 0.0 & 0.0 & 0.0 & 0.0 \\
\hline Ethiopia & - & P12 & 1,104 & 99.9 & 320 & 29.0 & 10 & 0.9 & 330 & 29.9 \\
\hline Egypt & - & P14 & 1,001 & 93.8 & 453 & 45.2 & 0.0 & 0.0 & 453 & 45.2 \\
\hline Nigeria & - & P7 & 924 & 181.2 & 0.0 & 0.0 & 282 & 30.5 & 282 & 30.5 \\
\hline Pakistan & - & P6 & 796 & 189.4 & 138 & 17.4 & 0.2 & 0.0 & 138 & 17.4 \\
\hline Turkey & - & P19 & 784 & 78.3 & 96 & 12.3 & 45 & 5.7 & 141 & 18.0 \\
\hline Thailand & - & P20 & 513 & 68.7 & 32 & 6.3 & 1.1 & 0.2 & 33 & 6.5 \\
\hline Japan & - & P11 & 378 & 128.0 & 0.2 & 0.1 & 0.0 & 0.0 & 0.2 & 0.1 \\
\hline Germany & - & P16 & 357 & 81.7 & 36 & 10.0 & 40 & 11.2 & 76 & 21.2 \\
\hline Vietnam & - & P15 & 332 & 93.6 & 90 & 27.2 & 0.1 & 0.0 & 90 & 27.2 \\
\hline Philippines & - & P13 & 300 & 101.7 & 78 & 25.9 & 0.0 & 0.0 & 78 & 25.9 \\
\hline
\end{tabular}

Table 6 Distribution of carbonate rocks in plains, hills and mountains (as defined by Sayre et al. 2014) on different continents and globally

\begin{tabular}{|c|c|c|c|c|c|c|}
\hline \multirow[t]{3}{*}{ Continent } & \multicolumn{6}{|c|}{ Total carbonate rock areas (CC, DC and mixed) } \\
\hline & \multicolumn{2}{|l|}{ Plains } & \multicolumn{2}{|l|}{ Hills } & \multicolumn{2}{|l|}{ Mountains } \\
\hline & $1,000 \mathrm{~km}^{2}$ & $\%$ & $1,000 \mathrm{~km}^{2}$ & $\%$ & $1,000 \mathrm{~km}^{2}$ & $\%$ \\
\hline Africa & 1,859 & 46.1 & 1,494 & 37.1 & 677 & 16.8 \\
\hline Asia & 1,322 & 16.0 & 2,017 & 24.4 & 4,915 & 59.6 \\
\hline Australia \& Oceania & 272 & 55.3 & 79 & 16.0 & 141 & 28.6 \\
\hline Europe & 787 & 36.9 & 730 & 34.2 & 617 & 28.9 \\
\hline North America & 1,875 & 44.2 & 1,110 & 26.2 & 1,258 & 29.6 \\
\hline South America & 71 & 9.4 & 168 & 22.1 & 520 & 68.5 \\
\hline World & 6,186 & 31.1 & 5,598 & 28.1 & 8,128 & 40.8 \\
\hline
\end{tabular}


Table 7 Total length of coastal carbonate rocks/coastal karst aquifers on continents and globally, expressed as absolute length in $1,000 \mathrm{~km}$ and percentage of the total coastline

\begin{tabular}{lll}
\hline \multirow{2}{*}{ Continent } & \multicolumn{2}{l}{ Length of coastal karst } \\
\cline { 2 - 3 } & $1,000 \mathrm{~km}$ & $\%$ \\
\hline Africa & 10.9 & 19.8 \\
Asia & 33.0 & 12.7 \\
Australia and Oceania & 12.7 & 17.8 \\
Europe & 26.3 & 18.6 \\
North America & 62.5 & 17.4 \\
South America & 5.9 & 7.6 \\
World & 151.4 & 15.7 \\
\hline
\end{tabular}

overexploitation and rapidly declining water tables ("groundwater mining"; Dirks et al. 2018; Schulz et al. 2016).

The relation between karst and climate is not straightforward, because every karst system is the result of a long and complex geologic and climatic history. Nevertheless, it is useful and interesting to analyze the occurrence of karst in different climatic zones. The Köppen-Geiger climate classification system is one of the most commonly used and has been updated and modified several times (Beck et al. 2018). It subdivides climates into five main groups on the basis of seasonal precipitation and temperature patterns: tropical, arid, temperate, cold, and polar (which also includes high mountain climates). These groups can be further subdivided into various climatic types, but for simplicity the statistical analysis focused on the five main groups. Results are displayed in Table 8 and on the map in Fig. 4.

The analysis revealed that 6.92 million $\mathrm{km}^{2}$ or $34.2 \%$ of all carbonate rocks are located in arid climates, followed by $28.2 \%$ in cold climates and $15.9 \%$ in temperate climates, whereas only 13.1 and $8.6 \%$ occur respectively in tropical and polar climates (Table 8 ). These percentages were calculated by dividing the karst surface area in the respective climate by the total global karst surface area.

The proportion of karst areas in each climatic zone was calculated by dividing the karst surface area in the respective climate by the total surface area of this climatic region (not shown in Table 8). The highest percentage was identified in temperate climates, where $19.1 \%$ of the land surface consists of carbonate rocks, followed by cold $(16.8 \%)$ and arid $(14.8 \%)$ climates, whereas only 8.8 and $7.7 \%$ of the land surface in the tropical and polar zones consists of carbonate rocks.

As a hypothesis, this distribution could be explained by the relatively good preservation of carbonate rocks in temperate, cold, and arid climates, compared to high chemical dissolution rates in tropical climates (see discussion by Ford and Williams 2007), and the widespread erosive removal of most sedimentary cover by the action of Pleistocene glaciers in the polar zone. However, the uneven distribution of rock types as a result of contrasts in local geologic history is a simpler and probably sufficient explanation.

The largest absolute areas of tropical karst occur in Africa $\left(1.05\right.$ million $\left.\mathrm{km}^{2}\right)$ and Asia $\left(0.67\right.$ million $\left.\mathrm{km}^{2}\right)$. Asia also has the largest carbonate rock areas in arid $\left(3.01\right.$ million $\left.\mathrm{km}^{2}\right)$, temperate $\left(1.47\right.$ million $\left.\mathrm{km}^{2}\right)$, cold $\left(2.37\right.$ million $\left.\mathrm{km}^{2}\right)$ and polar climates $\left(0.82\right.$ million $\left.\mathrm{km}^{2}\right)$, which also includes the Himalayas and Tibetan Plateau.

For water resources assessment, precipitation is the most relevant climatic parameter. Groundwater recharge can be expressed as specific flow rates (in $\mathrm{L} \mathrm{s}^{-1} \mathrm{~km}^{-2}$ ), effective rainfall (P-ETa, in mm years ${ }^{-1}$ ) or percentage of precipitation. Several studies report relatively high percentages of recharge in karst areas, due to thin soils and open fractures in the epikarst (Chen et al. 2018; Malard et al. 2016). However, determination of actual evapotranspiration and recharge are associated with high uncertainties in karst areas, where the extensions of recharge areas and,

Table 8 Occurrence of carbonate rocks/potential karst aquifers in the five main climatic groups of the Köppen-Geiger classification

\begin{tabular}{|c|c|c|c|c|c|c|c|c|c|c|}
\hline \multirow[t]{3}{*}{ Continent } & \multicolumn{10}{|c|}{ Total carbonate rock areas (CC, DC and mixed) } \\
\hline & \multicolumn{2}{|l|}{ Tropical } & \multicolumn{2}{|l|}{ Arid } & \multicolumn{2}{|l|}{ Temperate } & \multicolumn{2}{|l|}{ Cold } & \multicolumn{2}{|l|}{ Polar } \\
\hline & $1,000 \mathrm{~km}^{2}$ & $\%$ & $1,000 \mathrm{~km}^{2}$ & $\%$ & $1,000 \mathrm{~km}^{2}$ & $\%$ & $1,000 \mathrm{~km}^{2}$ & $\%$ & $1,000 \mathrm{~km}^{2}$ & $\%$ \\
\hline Africa & 1,048 & 25.9 & 2,676 & 66.0 & 326 & 8.0 & 3.4 & 0.1 & 0.0 & 0.0 \\
\hline Asia & 672 & 8.1 & 3,008 & 36.1 & 1,467 & 17.6 & 2,375 & 28.5 & 818 & 9.8 \\
\hline Australia \& Oceania & 62 & 12.4 & 282 & 56.2 & 156 & 31.1 & 0.7 & 0.1 & 0.6 & 0.1 \\
\hline Europe & 0.0 & 0.0 & 218 & 10.1 & 606 & 28.0 & 1,275 & 58.9 & 67 & 3.1 \\
\hline North America & 420 & 9.5 & 645 & 14.6 & 575 & 13.0 & 2,049 & 46.2 & 742 & 16.7 \\
\hline South America & 451 & 58.7 & 93 & 12.2 & 98 & 12.7 & 2.9 & 0.4 & 123 & 16.0 \\
\hline World & 2,653 & 13.1 & 6,923 & 34.2 & 3,228 & 15.9 & 5,706 & 28.2 & 1,751 & 8.6 \\
\hline
\end{tabular}




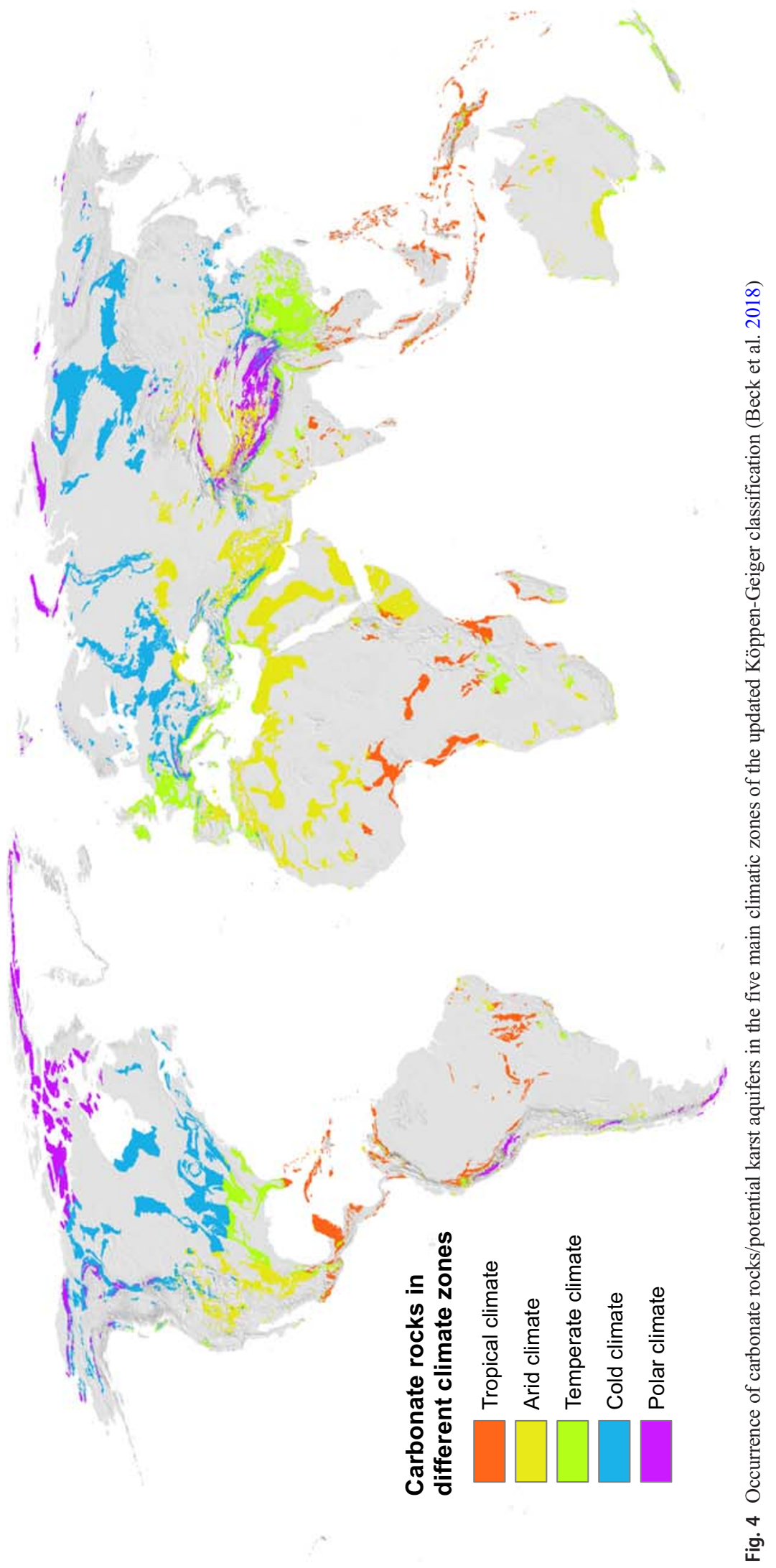




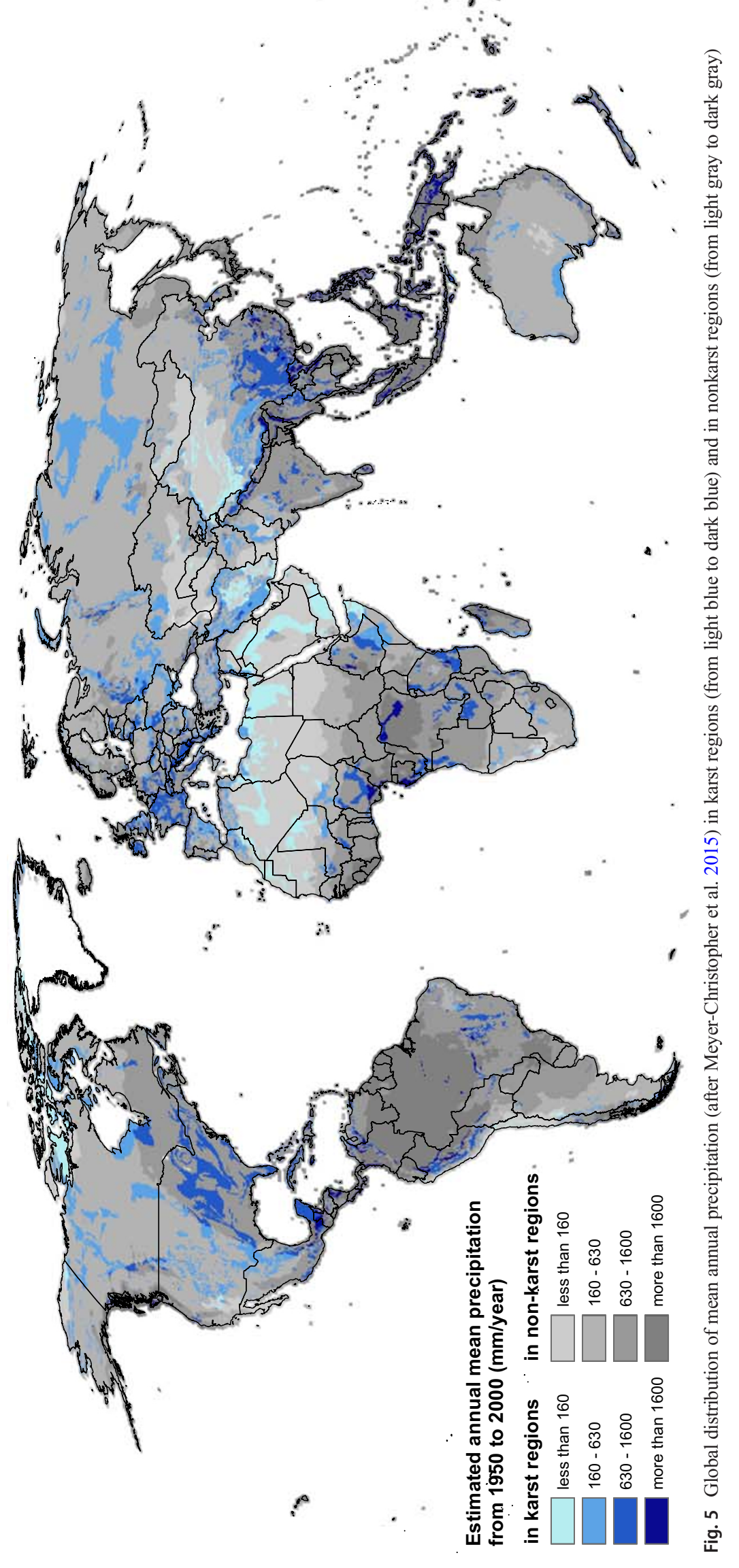


Table 9 Total population on continents and globally, in the years 1990, 2000 and 2015, and estimated population living on karst in 2000 and 2015, expressed as absolute numbers and percentage

\begin{tabular}{|c|c|c|c|c|c|c|c|c|c|}
\hline \multicolumn{4}{|c|}{ Estimated total population on continents } & \multicolumn{6}{|c|}{ Estimated population on karst } \\
\hline Name & 1990 (millions) & 2000 (millions) & 2015 (millions) & 1990 (millions) & $\%$ & 2000 (millions) & $\%$ & 2015 (millions) & $\%$ \\
\hline Africa & 585.0 & 748.3 & $1,044.7$ & 97.8 & 16.7 & 125.6 & 16.8 & 174.4 & 16.7 \\
\hline Asia & $3,197.6$ & $3,701.9$ & $4,390.9$ & 455.0 & 14.2 & 520.1 & 14.0 & 661.7 & 15.1 \\
\hline Australia and Oceania & 25.1 & 28.6 & 33.3 & 3.1 & 12.5 & 3.7 & 12.8 & 4.4 & 13.1 \\
\hline Europe & 688.3 & 696.1 & 680.3 & 175.0 & 25.4 & 176.5 & 25.4 & 172.1 & 25.3 \\
\hline North America & 431.2 & 490.8 & 571.5 & 107.1 & 24.8 & 119.3 & 24.3 & 134.2 & 23.5 \\
\hline South America & 293.7 & 343.9 & 415.8 & 23.6 & 8.0 & 28.0 & 8.1 & 34.3 & 8.2 \\
\hline World & $5,220.8$ & $6,009.5$ & $7,136.5$ & 861.7 & 16.5 & 973.2 & 16.2 & $1,181.1$ & 16.5 \\
\hline
\end{tabular}

consequently, water balances are difficult to define (Hartmann et al. 2012). Therefore, for pragmatic reasons, the global distribution of karst aquifers was analyzed with respect to annual precipitation using four classes, ranging from arid to very humid:

- $\quad<5 \mathrm{~L} \mathrm{~s}^{-1} \mathrm{~km}^{-2}\left(<160 \mathrm{~mm}\right.$ years $\left.^{-1}\right)$, in arid and semi-arid areas

- 5-20 $\mathrm{L} \mathrm{s}^{-1} \mathrm{~km}^{-2}$ (160-630 $\left.\mathrm{mm} \mathrm{years}^{-1}\right)$, e.g., in Mediterranean and temperate areas

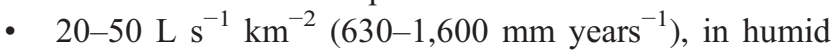
areas

- $\quad>50 \mathrm{~L} \mathrm{~s}^{-1} \mathrm{~km}^{-2}\left(>1,600 \mathrm{~mm}^{-1 e a r s}{ }^{-1}\right)$, in mountainous and very humid tropical areas

Figure 5 shows the distribution of these four precipitation zones in karst areas (from light blue to dark blue) and in nonkarst areas (from light grey to dark grey). This map is a first step toward more accurately quantifying the role of carbonate rocks and karst aquifers in the global water cycle.

\section{Karst and population}

In addition to climate change, population growth is a major challenge to water resources management (Vorosmarty et al. 2000). Therefore, the relations between karst and population were analyzed. Results are shown in Table 9 and on the map in Fig. 6. The analyses revealed that, in 2015, a total number of 1.18 billion people lived on karst areas, corresponding to $16.5 \%$ of the global population. Since 2015 , the global population has further increased to an estimated 7.7 billion people, so the best estimate of the current population (2019) living on karst is 1.3 billion. This number is about twice as high as the number of people using freshwater from karst aquifers recently estimated by Stevanovic (2019), but this is not necessarily a contradiction. The two numbers refer to different quantities and are not directly linked to each other, because geologic boundaries often do not coincide with water-supply boundaries.
The largest absolute number is in Asia, where 661.7 million people $(15.1 \%)$ live on karst, with a regional focus on China, as it can be seen on the map in Fig. 6. The highest percentages are in Europe and North America, where 25.3 and $23.5 \%$ of the populations live on karst areas.

\section{Conclusions and outlook}

This study presents the first comprehensive statistical analysis of WOKAM and was achieved by combining the WOKAM geodatabase with a variety of other publicly available global datasets. Although WOKAM includes both carbonate and evaporite rocks, all analyses presented in this paper focus entirely on carbonate rocks, because they are far more important in terms of water resources and more widespread on all continents and in all climatic zones than evaporite rocks. The major finding and conclusions can be summarized as in the following paragraphs.

Globally, $15.2 \%$ of the ice-free land surface is characterized by the presence of carbonate rock, which can be further divided into continuous (9.4\%) and discontinuous (5.8\%) karst regions. The highest percentage of karst is in Europe (21.8\%), followed by North America (19.6\%), Asia (18.6\%), Africa (13.5\%), Australia and Oceania (6.2\%) and South America (4.3\%). China has the largest absolute karst surface area $\left(2.54\right.$ million $\left.\mathrm{km}^{2}\right)$ and the highest percentage of karst (26.5\%) among the ten largest countries.

Concerning topography, $31.3 \%$ of all karst areas occur in plains, $28.1 \%$ in hilly landscapes and $40.8 \%$ in mountainous regions. About $151,400 \mathrm{~km}$ or $15.7 \%$ of the global coastlines are formed by carbonate rocks. The coast of the Dinaric Karst, the Yucatan Peninsula, Florida, Southern Australia and the Mediterranean coast of eastern Libya and Egypt are prime examples of coastal karst aquifers.

Carbonate rocks occur in all climatic zones, but their distribution is uneven. The highest percentage was identified in the temperate zone, where $19.1 \%$ of the land surface consists of carbonate rocks, followed by cold (16.8\%) and arid 


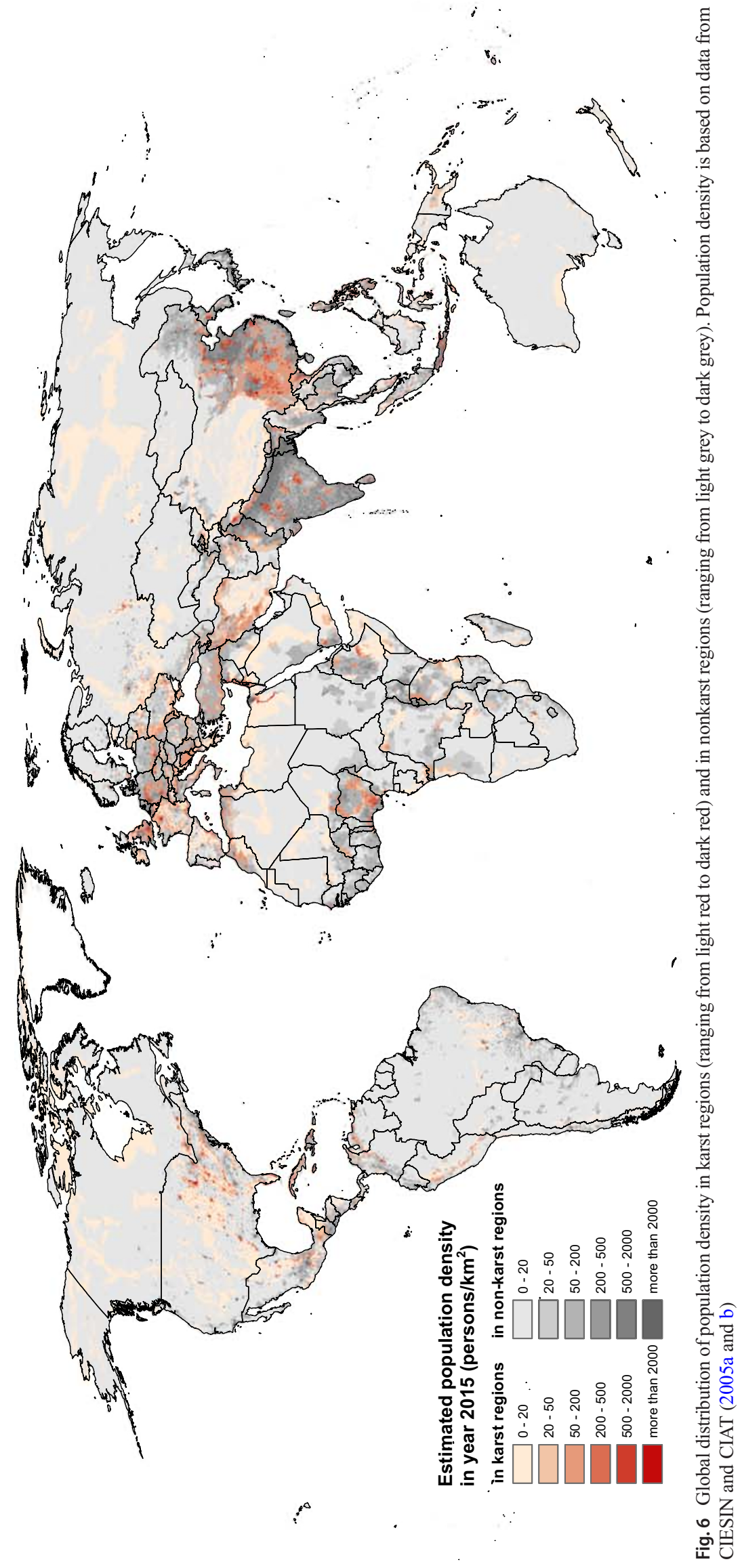


$(14.8 \%)$ climates, whereas the proportion of carbonate rocks is much lower in tropical $(8.8 \%)$ and polar $(7.7 \%)$ climatic regions.

Population growth is a major challenge for sustainable water resources management; therefore, the findings concerning the relation between karst and population are particularly relevant. In 2015, an estimated 1.18 billion people, corresponding to $16.5 \%$ of the global population, lived on karst. In 2019, this number might have reached 1.3 billion; however, the precise relation between the number of people living on karst and people supplied by freshwater from karst is very complex and could not be investigated in further detail within the scope of this study.

Karst terrains are not only relevant in terms of water resources, but also contain a variety of other natural resources and provide vital ecosystem functions. Therefore, WOKAM and the statistical data generated in this study are also relevant to biodiversity, cave conservation, soils and agriculture, archeological and cultural heritage, geo-tourism, and many other aspects of life on Earth.

Therefore, the publicly available WOKAM database has a great potential for scientific research and practical management applications at transregional, continental and global scales. For example, WOKAM can be used as a basis for:

- Improved global water balances and water management under conditions of climate change and population growth

- Better quantification of geochemical cycling with a focus on the carbon cycle

- Analyses concerning global biodiversity, both at the land surface and in the geologic underground

- Studies related to archeological and cultural heritage, because large parts of ancient human history are preserved in caves and karst areas

Acknowledgements The WOKAM project was part of the World-wide Hydrogeological Mapping and Assessment Programme (WHYMAP) executed under the umbrella of the UNESCO International Hydrological Programme (UNESCO-IHP). A network of 80 regional experts delivered data and helped to check and improve the map. A full list is available on the WOKAM website at BGR. We thank all colleagues for their valuable contributions. Special thanks to Bob Gulden for his highly useful online lists of the world's longest and deepest caves. We also thank Alice Aureli and Aurélien Dumont (UNESCO) for friendly support and cooperation during the project. The statistical analyses presented in this paper were done after completion of the WOKAM project in 2017, without external funding, and are beyond the project's initial scope. Last but not least, we would like to thank the associate editor Andrew Luhmann and the two reviewers Arthur Palmer and Daniel H. Doctor for their thorough and constructive reviews which helped to further improve the paper.

Funding information Open Access funding provided by Projekt DEAL. The project was partially financially supported by the International Association of Hydrogeologists (IAH) and UNESCO.

Open Access This article is licensed under a Creative Commons Attribution 4.0 International License, which permits use, sharing, adaptation, distribution and reproduction in any medium or format, as long as you give appropriate credit to the original author(s) and the source, provide a link to the Creative Commons licence, and indicate if changes were made. The images or other third party material in this article are included in the article's Creative Commons licence, unless indicated otherwise in a credit line to the material. If material is not included in the article's Creative Commons licence and your intended use is not permitted by statutory regulation or exceeds the permitted use, you will need to obtain permission directly from the copyright holder. To view a copy of this licence, visit http://creativecommons.org/licenses/by/4.0/.

\section{References}

Arfib B, de Marsily G, Ganoulis J (2007) Locating the zone of saline intrusion in a coastal karst aquifer using springflow data. Ground Water 45(1):28-35

Bailly-Comte V, Martin JB, Jourde H, Screaton EJ, Pistre S, Langston A (2010) Water exchange and pressure transfer between conduits and matrix and their influence on hydrodynamics of two karst aquifers with sinking streams. J Hydrol 386(1-4):55-66

Bakalowicz M (2005) Karst groundwater: a challenge for new resources. Hydrogeol J 13(1):148-160

Beck H, Zimmermann N, McVicar TR, Vergopolan N, Berg A, Wood E (2018) Present and future Köppen-Geiger climate classification maps at 1-km resolution. Scientific Data 5:180214. https://doi.org/ 10.1038/sdata.2018.214; Data available at http://www.gloh2o.org/ koppen/. Accessed 4 March 2019

BGR (2019) BGR Productcenter: World Karst Aquifer Map (WHYMAP WOKAM). https://doi.org/10.25928/b2.21_sfkq-r406. Accessed March 2019

Chen Z, Auler AS, Bakalowicz M, Drew D, Griger F, Hartmann J, Jiang G, Moosdorf N, Richts A, Stevanovic Z, Veni G, Goldscheider N (2017a) The world karst aquifer mapping project: concept, mapping procedure and map of Europe. Hydrogeol J 25(3):771-785

Chen Z, Goldscheider N, Auler AS, Bakalowicz M, Broda S, Drew D, Hartmann J, Jiang G, Moosdorf N, Richts A, Stevanovic Z, Veni G, Dumont A, Aureli A, Clos P, Krombholz M (2017b) World Karst Aquifer Map (WHYMAP WOKAM). BGR, IAH, KIT, UNESCO. https://doi.org/10.25928/b2.21_sfkq-r406

Chen Z, Hartmann A, Wagener T, Goldscheider N (2018) Dynamics of water fluxes and storages in an Alpine karst catchment under current and potential future climate conditions. Hydrol Earth Syst Sci 22(7): 3807-3823

Clements R, Sodhi NS, Schilthuizen M, Ng PKL (2006) Limestone karsts of Southeast Asia: imperiled arks of biodiversity. Bioscience 56(9): 733-742

CIESIN and CIAT (2005a) Gridded Population of the World, Version 3 (GPWv3): population density grid. NASA Socioeconomic Data and Applications Center (SEDAC). Data available at: https://doi.org/10. 7927/H4XK8CG2. Accessed 4 March 2019

CIESIN and CIAT (2005b), Gridded Population of the World, Version 3 (GPWv3): population density grid, future estimates. NASA Socioeconomic Data and Applications Center (SEDAC), Data available at: https://doi.org/10.7927/H4ST7MRB. Accessed 4 March 2019

Dirks H, Al Ajmi H, Kienast P, Rausch R (2018) Hydrogeology of the Umm Er Radhuma aquifer (Arabian Peninsula). Grundwasser 23(1): $5-15$

Dreybrodt W (1990) The role of dissolution kinetics in the development of karstification in limestone: a model simulation of karst evolution. J Geol 98:639-655 
Feeser I, O'Connell M (2009) Fresh insights into long-term changes in flora, vegetation, land use and soil erosion in the karstic environment of the Burren, western Ireland. J Ecol 97(5):1083-1100

Ford D (1987) Effects of glaciations and permafrost upon the development of karst in Canada. Earth Surf Process Landf 12(5):507-521

Ford D, Williams PW (2007) Karst hydrogeology and geomorphology. Wiley, Chichester, pp 576

Gabrovsek F (2009) On concepts and methods for the estimation of dissolutional denudation rates in karst areas. Geomorphology 106(1-2):9-14

Goldscheider N (2005) Karst groundwater vulnerability mapping: application of a new method in the Swabian Alb, Germany. Hydrogeol J 13(4):555-564

Goldscheider N (2019) A holistic approach to groundwater protection and ecosystem services in karst terrains. Carbon Evapor 34(4): 1241-1249. https://doi.org/10.1007/s13146-019-00492-5

Goldscheider N, Drew D (2007) Methods in karst hydrogeology. Taylor and Francis, London, 264 pp

Goldscheider N, Madl-Szonyi J, Eross A, Schill E (2010) Review: Thermal water resources in carbonate rock aquifers. Hydrogeol $\mathrm{J}$ 18(6):1303-1318

Gulden B (2020) World's longest caves/world's deepest caves. www. caverbob.com. Accessed 21 Feb 2020

Hartmann A, Lange J, Weiler M, Arbel Y, Greenbaum N (2012) A new approach to model the spatial and temporal variability of recharge to karst aquifers. Hydrol Earth Syst Sci 16(7):2219-2231

Hartmann A, Goldscheider N, Wagener T, Lange J, Weiler M (2014) Karst water resources in a changing world: review of hydrological modeling approaches. Rev Geophys 52(3):218-242

Hartmann J, Moosdorf N (2012) The new global lithological map database GLiM: a representation of rock properties at the Earth surface. Geochem Geophys Geosyst 13(12). https://doi.org/10.1029/ 2012GC004370

Hartmann J, Jansen N, Duerr HH, Kempe S, Koehler P (2009) Global CO $2^{-}$ consumption by chemical weathering: what is the contribution of highly active weathering regions? Glob Planet Chang 69(4):185-194

Hobbs SL, Gunn J (1998) The hydrogeological effect of quarrying karstified limestone: options for prediction and mitigation. Q J Eng Geol Hydrogeol 31:147-157

Kresic N, Stevanovic Z (2010) Groundwater hydrology of springs: engineering, theory, management, and sustainability. ButterworthHeinemann, Oxford

Liu ZH, Dreybrodt W, Wang HJ (2010) A new direction in effective accounting for the atmospheric $\mathrm{CO}_{2}$ budget: considering the combined action of carbonate dissolution, the global water cycle and photosynthetic uptake of DIC by aquatic organisms. Earth Sci Rev 99(3-4):162-172

Malard A, Sinreich M, Jeannin PY (2016) A novel approach for estimating karst groundwater recharge in mountainous regions and its application in Switzerland. Hydrol Process 30(13):2153-2166
Meyer-Christoffer A, Becker A, Finger P, Rudolf B, Schneider U, Ziese M (2015) GPCC Climatology version 2015 at $0.25^{\circ}$ : monthly landsurface precipitation climatology for every month and the total year from rain-gauges built on GTS - based and historic data. https://doi. org/10.5676/DWD GPCC/CLIM M V2015 025

Olarinoye T, Gleeson T, Marx V, Seeger S, Adinehvand R, Allocca V, Andreo B, Apaéstegui J, Apolit C, Arfib B, Auler A, Barberá JA, Batiot-Guilhe C, Bechtel T, Binet S, Bittner D, Blatnik M, Bolger T, Brunet P, Charlier JB, Chen Z, Chiogna G, Coxon G, De Vita P, Doummar J, Epting J, Fournier M, Goldscheider N, Gunn J, Guo F, Guyot JL, Howden N, Huggenberger P, Hunt B, Jeannin P-Y, Jiang G, Jones G, Jourde H, Karmann I, Koit O, Kordilla J, Labat D, Ladouche B, Serena Liso I, Liu Z, Massei N, Mazzilli N, Mudarra M, Parise M, Pu J, Ravbar N, Hidalgo Sanchez L, Santo A, Sauter M, Sivelle V, Øvrevik Skoglund R, Stevanovic Z, Wood C, Worthington S, Hartmann A (2020) Global karst springs hydrograph dataset for research and management of the world's fastest-flowing groundwater. Sci Data 7, 59. https://doi.org/10.1038/s41597-0190346-5

Pinault JL, Doerfliger N, Ladouche B, Bakalowicz M (2004) Characterizing a coastal karst aquifer using an inverse modeling approach: the saline springs of Thau, southern France. Water Resour Res 40(8). https://doi.org/10.1029/2003WR002553

Sayre R, Dangermond J, Frye C, Vaughan R, Aniello P, Breyer S, Cribbs D, Hopkins D, Nauman R, Derrenbacher W, Wright D, Brown C, Convis C, Smith J, Benson L, Paco VanSistine D, Warner H, Cress J, Danielson J, Hamann S, Cecere T, Reddy A, Burton D, Grosse A, True D, Metzger M, Hartmann J, Moosdorf M, Dürr H, Paganini M, DeFourny P, Arino O, Maynard S, Anderson M, Comer P (2014) A new map of global ecological land units: an ecophysiographic stratification approach. Association of American Geographers, Washington, DC. Data available at: http://rmgsc.cr.usgs.gov/ outgoing/ecosystems/Global/. Accessed 4 March 2019

Schulz S, de Rooij GH, Michelsen N, Rausch R, Siebert C, Schueth C, Al-Saud M, Merz R (2016) Estimating groundwater recharge for an arid karst system using a combined approach of time-lapse camera monitoring and water balance modelling. Hydrol Process 30(5): $771-782$

Stevanovic Z (2019) Karst waters in potable water supply: a global scale overview. Environ Earth Sci 78(23):662. https://doi.org/10.1007/ s12665-019-8670-9

Sket B (1999) High biodiversity in hypogean waters and its endangerment: the situation in Slovenia, the Dinaric karst, and Europe. Crustaceana 72:767-779

UN (2017) World Population Prospects 2017. United Nations, Department of Economic and Social Affairs, Division of Population, New York

Vorosmarty CJ, Green P, Salisbury J, Lammers RB (2000) Global water resources: vulnerability from climate change and population growth. Science 289(5477):284-288 